\title{
Antibacterial Effect of Surface Pre-Reacted Glass Ionomer Filler and Eluate - Mini Review
}

Masahiro Yoneda*, Nao Suzuki and Takao Hirofuji

Section of General Dentistry, Department of General Dentistry, Fukuoka Dental College, Japan

\begin{abstract}
A composite resin containing surface pre-reacted glass ionomer(S-PRG) has become widely used as filler or other dental materials in dental treatment. In this mini-review, we briefly summarizethe antibacterial activities of S-PRG on different oral bacteria. The inhibitory effect of S-PRG on plaque formation in the oral cavity has been observed. Streptococcus mutans adherence has been shown to be inhibited by S-PRG. S-PRG is also considered to be effective in caries prevention because S-PRG eluate could inhibit biofilm formation and disrupt salivary mature polymicrobial biofilm. S-PRG eluate has suppressed the protease and gelatinase activities of Porphyromonas gingivalis, which is one of the most important periodontopathic bacteria. Coaggregation by $P$. gingivali sand Fusobacterium nucleatum was also inhibited by S-PRG eluate. Other work has shown that an endodontic sealer containing S-PRGhad an antibacterial effect on some endodontic bacteria. Oral rinsing with S-PRG eluate was also effective in reducing oral malodor production. In this way, S-PRG has antibacterial effect, and it will be further applied for various dental materials and contribute to preventing oral diseases.
\end{abstract}

Keywords: Surface pre-reacted glass ionomer; Antibacterial effect; Adhesion; Ion release

\section{Introduction}

Dental caries and periodontitis are two major causes of tooth loss in adults. To reduce dental caries, it is necessary to prevent demineralization of the intact tooth surface and to promote remineralization of early stage tooth decay. Once irreversible caries are formed, restorative materials are applied as a treatment. However, secondary caries, which is caries lesion developed adjacent to restorations, is the next problem and is the main cause for the replacement of restorative materials.

To overcome these problems, much research on dental materials has been performed. Glass ionomer cement (GIC) is known to have an ion exchange and fluoride release activity, which results in interfering with cariogenic bacteria and remineralization [1-5]. However, because of the lack of hardness, GICs are not applied in cases where high occlusal loading is expected [6]. A composite resin containing prereacted glass ionomer(S-PRG) filler has become widely used in dental treatment [7]. The S-PRG filler particles are formed by an acid-base reaction between fluoroaluminosilicate glass and polyacrylic acid [8]. S-PRG fillers are capable of fluoride release and recharge [9-11]. S-PRG is also known to release several types of ions, including $\mathrm{Al}, \mathrm{B}, \mathrm{Na}, \mathrm{Si}$, Srand F [12]. The functions of these ions are summarized in Table 1. Anti-demineralization effects of S-PRG have been observed in denture base resin [13], fissure sealant [14, 15], and coating materials [16-18]. S-PRG has like-re-mineralizing ability [19-21], which is considered to come from its ion-releasing ability. The effects of S-PRG filler and its released ions on hard tissue were extensively investigated, including the anti-demineralization and re-mineralization activity. The bioactivity was also detected when using an S-PRG eluate [12]. It is also important

\begin{tabular}{|c|l|}
\hline Ions & \multicolumn{1}{c|}{ Functions } \\
\hline $\mathrm{F}$ & $\begin{array}{l}\text { fluoroapatite production, antibacterial effect, remineralization of } \\
\text { demineralized lesions }\end{array}$ \\
\hline $\mathrm{Sr}$ & improvement of bone formation and mineralization \\
\hline $\mathrm{Al}$ & suppression of hypersensitivity \\
\hline $\mathrm{Si}$ & remineralization of tooth \\
\hline $\mathrm{B}$ & antibacterial effect, promotion of bone formation \\
\hline
\end{tabular}

Table 1: lons released from S-PRG and their functions. to control cariogenic bacteria to prevent caries formation, and work has been done to describe the antibacterial effects of S-PRG. Oral microorganisms cause other diseases such as periodontitis, periapical lesions, oral malodor and so on. In this mini-review, the information on S-PRG was collected through Pub-Med and Japanese journal index system, and the effects of S-PRG on cariogenic and periodontopathic bacteria are briefly summarized.

\section{Inhibitory effect of S-PRG on plaque formation in the oral cavity}

Controlling the levels of bacteria is an effective strategy to maintain dental health. It is important to reduce the amount of plaque on the surface of dental materials in the oral cavity. Early-stage research was performed on in vivo antiplaque activity. Small resin blocks were attached to the tooth surface and the amount of bacteria on the resin surface was observed after removing the blocks from the oral cavity. Scanning electron microscopy revealed many bacteria on the control resin blocks. In contrast, a much smaller amount of bacteria was attached to the S-PRG resin surface [22-26]. Bacterial adherence is the first step in caries initiation, and S-PRG-containing materials are considered to be less susceptible to cariogenic bacteria.

\section{Film-like layers on saliva-soaked S-PRG}

When S-PRG resin blocks were soaked in human saliva, thin filmlike layers were observed [23] and more albumin was absorbed onto

*Corresponding author: Masahiro Yoneda, Section of General Dentistry, Department of General Dentistry, Fukuoka Dental College, 2-15-1, Tamura Sawara-ku, Fukuoka, 814-0193, Japan, Tel: +81-92-801-0411; Fax: +81-92-8014909; E-mail:Yoneda@college.fdcnet.ac.jp

Received February 20, 2015; Accepted March 06, 2015; Published March 13 2015

Citation: Yoneda M, Suzuki N, Hirofuji T (2015) Antibacterial Effect of Surface PreReacted Glass lonomer Filler and Eluate-Mini Review. Pharm Anal Acta 6: 349 doi:10.4172/2153-2435.1000349

Copyright: @ 2015 Yoneda M, et al. This is an open-access article distributed under the terms of the Creative Commons Attribution License, which permits unrestricted use, distribution, and reproduction in any medium, provided the original author and source are credited. 
Citation: Yoneda M, Suzuki N, Hirofuji T (2015) Antibacterial Effect of Surface Pre-Reacted Glass lonomer Filler and Eluate-Mini Review. Pharm Anal Acta 6: 349. doi:10.4172/2153-2435.1000349

Page 2 of 5

the S-PRG surface when compared with control blocks [27]. Using $\mathrm{X}$-ray energy-dispersive spectroscopy, several ions such as $\mathrm{Al}, \mathrm{Si}$ and $\mathrm{Sr}$ were predominantly detected [24]. The amount of these ions was much higher in the layers on S-PRG resin blocks than on other resin surfaces. The ions are considered to be released from S-PRG and these ions may be responsible for the prevention of bacterial adherence.

\section{Effect on streptococci}

Streptococci are known as early-colonizers in dental plaque formation. An effective method of caries and secondary caries prevention is to reduce the attachment of these bacteria onto the surface of dental materials. The adherence of Streptococci has been examined in various ways. The adherence of Streptococcus mutans, the most cariogenic bacterium, to the surface of S-PRG was lower than that to other control resins [28-32]. There was a weaker or no effect on the attachment by other Streptococci such as S. oralis, S. salivarius, and $S$. sanguinis $[22,25,26]$. Theadhesion inhibition activity of S-PRG seemed to be limited to only some bacteria. The reason for this is not clear and the mechanism of bacterial adherence and inhibition by S-PRG need to be clarified. S-PRG also affected the $\mathrm{pH}$ decrease and demineralization caused by $S$. mutans [33]. S-PRG did not have a bactericidal effects on Streptococci [26,29], but it had some growth inhibition in liquid medium [34].

\section{Effect on in vitro polymicrobial biofilm}

In the oral cavity, the plaque is not composed of one bacterium, but composed of many different microorganisms. Therefore, it is important to examine the effect of S-PRG on the polymicrobial biofilm. Kuramochi et al. showed that S-PRG had a suppressive effect on the polymicrobial biofilm with salivary bacteria [35]. Suzuki et al. reported

\begin{tabular}{|c|c|c|c|c|c|}
\hline Authors & Target & Assay methods & Function & Result & References \\
\hline \multirow[t]{2}{*}{ Nishio et al. } & human dental plaque & SEM $^{1}$ & plaque formation & less plaque formation & 22 \\
\hline & S. oralis & $\begin{array}{l}\text { SEM, labeled bacterial } \\
\text { count }\end{array}$ & adherence & no difference & \\
\hline \multirow[t]{2}{*}{ Honda et al. } & human dental plaque & SEM & plaque formation & less plaque formation & 23 \\
\hline & huma saliva & EDS & film-like interface substance & anti-bacterial layer formation & \\
\hline \multirow[t]{2}{*}{ Hirose et al. } & Streptococci & SEM & adherence & less S. sanguinisadherence & 27 \\
\hline & albumin & 125|-labeled albumin & albumin adsorption & more albumin adsorption & \\
\hline \multirow[t]{2}{*}{ Tamoto et al. } & human dental plaque & SEM & plaque formation & less plaque formation & 24 \\
\hline & & EDS & film-like interface substance & $\begin{array}{c}\mathrm{Al}, \mathrm{Si} \text {, and } \mathrm{Sr} \text { were detected from the } \\
\text { thin layer }\end{array}$ & \\
\hline Han et al. & $\begin{array}{l}P . \text { acnes, } A \text {. israelii, } E . \\
\text { faecalis }\end{array}$ & agar difusion method & antibacterial test & $\begin{array}{l}\text { anti-bacterial effect on } P \text {. acnes, } A \text {. } \\
\text { israelii }\end{array}$ & 37 \\
\hline Daneshmehr et al. & S. mutans & SEM & biofilm formation & less biofilm formation & 28 \\
\hline \multirow[t]{2}{*}{ Yoshida et al. } & human dental plaque & SEM & plaque formation & less plaque formation & 25 \\
\hline & $\begin{array}{l}\text { S. sanguinis, S. salivarius, } \\
\text { S. oralis }\end{array}$ & ${ }^{3} \mathrm{H}$-labeled bacterial count & adherence & no difference & \\
\hline \multirow[t]{3}{*}{ Idono et al. } & human dental plaque & SEM & plaque formation & less plaque formation & 26 \\
\hline & S. oralis & SEM & adherence & less adherence & \\
\hline & S. oralis & colony count & antibacterial test & no difference & \\
\hline \multirow[t]{2}{*}{ Saku et al. } & S. mutans & $\begin{array}{l}\text { SEM, }{ }^{3} \mathrm{H} \text {-labeled bacterial } \\
\text { count }\end{array}$ & adherence & less adherence & 29 \\
\hline & S. mutans & colony count & antibacterial test & no difference & \\
\hline Tamura et al. & S. sanguie and S. oralis & growth curve examination & growth inhibition & growth inhibition & 34 \\
\hline Kimyai et al. & S. mutans & SEM, bacterial count & adherence & less adherence & 30 \\
\hline \multirow[t]{2}{*}{ Ma et al. } & S. mutans & $\mathrm{pH}$ electrode & $\mathrm{pH}$ change & less $\mathrm{pH}$ decrease & 33 \\
\hline & S. mutans & micro-CT scanning, SEM & demineralization & less demineralization & \\
\hline \multirow[t]{3}{*}{ Yoneda et al. } & S. mutans & $\begin{array}{c}\text { safranin-based micoplate } \\
\text { assay }\end{array}$ & adherence & less adherence & 38 \\
\hline & $P$. gingivalis & BAPNA $^{2}$, gelatin film assay & enzyme activities & less enzyme activities & \\
\hline & $\begin{array}{l}P . \text { gingivalisand } F \text {. } \\
\text { nucleatum }\end{array}$ & coaggregation assay & coaggregation & less coaggregation & \\
\hline \multirow[t]{2}{*}{ Hotta et al. } & S. mutans & $\begin{array}{l}\text { SEM, labeled bacterial } \\
\text { count }\end{array}$ & adherence & less adherence & 31 \\
\hline & S. sanguinis & $\begin{array}{c}\text { SEM, }{ }^{3} \mathrm{H} \text {-labeled bacterial } \\
\text { count }\end{array}$ & adherence & no difference & \\
\hline Kuramochi et al. & huma saliva & $\begin{array}{l}\text { bacterial count of PM } \\
\text { biofilm }{ }^{3}\end{array}$ & biofilm formation & less biofilm formation & 35 \\
\hline Hahnel et al. & S. mutans & $\begin{array}{l}\text { MTT-based microplate } \\
\text { assay }\end{array}$ & biofilm formation & less biofilm formation & 32 \\
\hline \multirow[t]{3}{*}{ Suzuki et al. } & huma saliva & colony count & antibacterial test & less viable bacteria & 36 \\
\hline & huma saliva & $\begin{array}{l}\text { safranin-based micoplate } \\
\text { assay }\end{array}$ & $\begin{array}{l}\text { biofilm formation and } \\
\text { disruption }\end{array}$ & $\begin{array}{l}\text { less biofilm formation and biofilm } \\
\text { disuruptive effect }\end{array}$ & \\
\hline & oral molodor & halimeter assay & VSCs ${ }^{4}$ produciton & less VSCs production & \\
\hline
\end{tabular}

${ }^{1}$ scanning electron microscopy

${ }^{2} \mathrm{Na}$-benzoyl-L-arginine 4-nitroanilide hydrochloride

${ }^{3}$ polymicrobial biofilm

${ }^{4}$ volatile sulfur compounds

Table 2: Antibacterial effect of S-PRG. 
that S-PRG could disrupt salivary mature polymicrobial biofilm as well as inhibit the formation of the biofilm [36].

\section{Effect on endodontic bacteria}

Periapical lesions are caused by bacterial infection, and it is important to control bacteria to prevent recurrence. S-PRG is not only used for restoration, but is also used for endodontic sealer. Han et al. performed experiments on endodontic bacteria. An endodontic sealer containing S-PRG had an antibacterial effect on Propionibacterium acnes and Actinomyces israelii, but had no effect on Enterococcus faecalis [37]. It is impossible to make the endodontic environment free from bacteria, so antibacterial sealer is effective for preventing recurrence of periapical lesions.

\section{Effect on enzyme activities of Porphyromonas gingivalis}

Some dental materials are applied to the area adjacent to the gingival margin, and the antibacterial materials will be effective in preventing periodontal diseases. S-PRG suppressed the protease and gelatinase activities of $P$. gingivalis [38], which is associated with the progression of periodontal disease. Some materials that inhibit the protease activity of $P$. gingivalis have been developed, but most of them are in liquid form, while S-PRG shows antibacterial activity as both a solid form material or its eluate. S-PRG is considered to have long-lasting activity to prevent periodontal diseases. Gelatinase is also related to the progression of secondary caries underneath tooth restorations $[39,40]$. Santos et al. reported that zinc oxide cement and amalgam suppressed gelatinase activity, which may contribute to the caries preventive effects of these materials [41]. It is already known that S-PRG limits caries progression because it releases fluoride $[12,42]$, but we found that it may additionally prevent secondary caries by inhibiting gelatinase activity at restoration sites.

\section{Effect on co-aggregation of periodontopathic bacteria}

It is well known that mixed infection of different kinds of bacteria is important to the initiation and progression of periodontal diseases [43]. We have previously shown that mixed infection of $P$. gingivalis and other microorganism enhances their virulence [44]. Co-aggregation of periodontopathic bacteria is associated with bacterial attachment in the gingival crevice [45]. Fusobacterium nucleatum is known to have a coaggregation activity, which is considered to be its virulence factor [46]. Yoneda et al. reported that S-PRG also disturbed the co-aggregation between $P$. gingivalis and $F$. nucleatum in a dose-dependent manner [38].

\section{Effect on oral malodor}

Oral malodor is associated with volatile sulfur compounds (VSCs) produced by periodontopathic bacteria [47,48]. Clinically, oral malodor is caused by tongue coating, periodontitis, and deep caries. Unclean denture is also one of the causes of halitosis [49], and antibacterial denture made with S-PRG will contribute to malodor prevention. Suzuki et al. reported that S-PRG rinsing eliminated more bacteria from the oral cavity when compared with water rinsing [36]. They also revealed that oral rinsing with an S-PRG eluate was effective in reducing VSCs production.

\section{Overall review of antibacterial activities of S-PRG}

S-PRG is known to release various ions, including $\mathrm{F}, \mathrm{Al}, \mathrm{Sr}, \mathrm{SiO}$, $\mathrm{B}$ and $\mathrm{Na}[12,50]$. Boron is known to have an antibacterial activity in cutaneous diseases and periodontitis [51,52], and inhibits bacterial and fungal quorum sensing [53]. Quorum sensing is a key factor in biofilm formation, so inhibition of this function in Streptococci may be a good candidate for the mechanism underlying the actions of S-PRG. In $P$. gingivalis, the mechanism responsible for S-PRG actions may involve the control of metal salts and ions that regulate bacterial enzyme activity. Gingipains, which are the major cysteine protease of $P$. gingivalis are known to require metal ions to achieve maximum enzyme activity [54], whereas gelatinases are inhibited by metal salts [55]. Thus, S-PRG may affect enzyme activity by modulating the concentrations of these metal salts and ions.

Bio-active properties of dental restorative materials are obtaining attention. Dental restoration is expected to induce "super dentin", which is more resistant to acid and base when comparedwith original dentin [56]. Antibacterial effects are highlighted as one of the bioactive properties [57]. Imazato reported the antibacterial effect of monomer methacryloxydodecyl pyridinium bromide [58]. In this way, the antibacterial activity of S-PRG will be more thoroughly investigated and it will be further applied for various dental materials and contribute to preventing caries, periodontitis and other oral diseases.

\section{Conclusion}

S-PRG has inhibited the adherence of cariogenic bacteria in vitro, and it had antiplaque activity in vivo. S-PRG eluate disrupted mature biofilm as well as inhibited biofilm formation. Enzyme and co-aggregation activity of periodontopathic bacteria was suppressed by S-PRG eluate. S-PRG-containing sealer suppressed endodontic bacteria. Oral rinsing with S-PRG eluate eliminated bacteria and diminished oral malodor. The various antibacterial effects were summarized in Table 2.

\section{References}

1. Benelli EM, Serra MC, Rodrigues AL Jr, Cury JA (1993) In situ anticariogenic potential of glass ionomer cement. Caries Res 27: 280-284.

2. Nakajo K, Imazato S, Takahashi Y, Kiba W, Ebisu S, et al. (2009) Fluoride released from glass-ionomer cement is responsible to inhibit the acid production of caries-related oral streptococci. Dent Mater 25: 703-708.

3. Seppä L, Torppa-Saarinen E, Luoma H (1992) Effect of different glass ionomers on the acid production and electrolyte metabolism of Streptococcus mutans Ingbritt. Caries Res 26: 434-438.

4. Dionysopoulos P, Kotsanos N, Koliniotou-Koubia E, Tolidis K (2003) Inhibition of demineralization in vitro around fluoride releasing materials. J Oral Rehabil 30: $1216-1222$.

5. Wiegand A, Buchalla W, Attin T (2007) Review on fluoride-releasing restorative materials--fluoride release and uptake characteristics, antibacterial activity and influence on caries formation. Dent Mater 23: 343-362.

6. Papacchini F, Goracci C, Sadek FT, Monticelli F, Garcia-Godoy F, et al. (2005) Microtensile bond strength to ground enamel by glass-ionomers, resin-modified glass-ionomers, and resin composites used as pit and fissure sealants. J Dent 33: $459-467$

7. Ikemura K, Tay FR, Endo T, Pashley DH (2008) A review of chemical-approach and ultramorphological studies on the development of fluoride-releasing dental adhesives comprising new pre-reacted glass ionomer (PRG) fillers. Dent Mater J 27: 315-339.

8. Ikemura K, Tay FR, Kouro Y, Endo T, Yoshiyama M, et al. (2003) Optimizing filler content in an adhesive system containing pre-reacted glass-ionomer fillers. Dent Mater 19: 137-146.

9. Han L, Cv E, Li M, Niwano K, Ab N, et al. (2002) Effect of fluoride mouth rinse on fluoride releasing and recharging from aesthetic dental materials. Dent Mater J 21: 285-295

10. Han L, Okamoto A, Fukushima M, Okiji T (2006) Evaluation of a new fluoridereleasing one-step adhesive. Dent Mater J 25: 509-515.

11. Kamijo K, Mukai Y, Tominaga T, Iwaya I, Fujino F, et al. (2009) Fluoride release 
and recharge characteristics of denture base resins containing surface prereacted glass-ionomer filler. Dent Mater J 28: 227-233

12. Fujimoto Y, Iwasa M, Murayama R, Miyazaki M, Nagafuji A, et al. (2010) Detection of ions released from S-PRG fillers and their modulation effect. Dent Mater J 29: 392-397.

13. Mukai Y, Kamijo K, Fujino F, Hirata Y, Teranaka T, et al. (2009) Effect of denture base-resin with prereacted glass-ionomer filler on dentin demineralization. Eur J Oral Sci 117: 750-754.

14. Shimazu K, Ogata K, Karibe H (2012) Caries-preventive effect of fissure sealant containing surface reaction-type pre-reacted glass ionomer filler and bonded by self-etching primer. J Clin Pediatr Dent 36: 343-347.

15. Kaga M, Kakuda S, Ida Y, Toshima H, Hashimoto M, et al. (2014) Inhibition of enamel demineralization by buffering effect of S-PRG filler-containing dental sealant. Eur J Oral Sci 122: 78-83.

16. Ma S, Imazato S, Chen JH, Mayanagi G, Takahashi N, et al. (2012) Effects of a coating resin containing S-PRG filler to prevent demineralization of root surfaces. Dent Mater J 31: 909-915.

17. Murayama R, Furuichi T, Yokokawa M, Takahashi F, Kawamoto R, et al. (2012) Ultrasonic investigation of the effect of S-PRG filler-containing coating material on bovine tooth demineralization. Dent Mater J 31: 954-959.

18. Shiiya T, Mukai Y, Tomiyama K, Teranaka T (2012) Anti-demineralization effect of a novel fluoride-releasing varnish on dentin. Am J Dent 25: 347-350.

19. Ito S, lijima M, Hashimoto M, Tsukamoto N, Mizoguchi I, et al. (2011) Effects of surface pre-reacted glass-ionomer fillers on mineral induction by phosphoprotein. J Dent 39: 72-79.

20. lijima M, Ito S, Nakagaki S, Kohda N, Muguruma T, et al. (2014) Effects of immersion in solution of an experimental toothpaste containing S-PRG filler on like-remineralizing ability of etched enamel. Dent Mater J 33: 430-436.

21. Hosoya Y, Ando S2, Otani H3, Yukinari T4, Miyazaki M2, et al. (2013) Ability of barrier coat S-PRG coating to arrest artificial enamel lesions in primary teeth. Am J Dent 26: 286-290.

22. Nishio M, Yamamoto K (2002) The anti-dental plaque effect of fluoride releasing light-cured composite resin restorative material. Jpn J Conserv Den 45: $459-468$

23. Honda T, Saku S, Yamamot K (2004) Study on the film layer product from S-PRG filler. Jpn J Conserv Dent 47: 391-402.

24. Tamoto A, Saku S, Yamamoto K (2006) Research on adaptaion and antiplaque property of flowable composite resins containing improved S-PRG filler. Jpn J Conserv Dent 49: 658-668.

25. Yoshida K, Saku S, Oohashi S, Yamamoto K (2008) Anti-plaque of new fluoride release adhesion system. Jpn J Conserv Dent 51: 493-501.

26. Idono T, Saku S, Yamamoto K (2009) The application of glass filler with fluoride to tooth coating materials. Jpn J Conserv Dent 52: 237-247.

27. Hirose M, Saku S, Yamamoto K (2006) Analysis of film layer formed on S-PRG resin surface. Jpn J Conserv Dent 49: 309-319.

28. Daneshmehr L, Matin K, Nikaido T, Tagami J (2008) Effects of root dentin surface coating with all-in-one adhesive materials on biofilm adherence. J Dent 36: $33-41$

29. Saku S, Kotake H, Scougall-Vilchis RJ, Ohashi S, Hotta M, et al. (2010) Antibacterial activity of composite resin with glass-ionomer filler particles. Dent Mater J 29: 193-198.

30. Kimyai S, Lotfipour F, Pourabbas R, Sadr A, Nikazar S, et al. (2011) Effect of two prophylaxis methods on adherence of Streptococcus mutans to microfilled composite resin and giomer surfaces. Med Oral Patol Oral Cir Bucal 16: e561567

31. Hotta M, Morikawa T, Tamura D, Kusakabe S (2014) Adherence of Streptococcus sanguinis and Streptococcus mutans to saliva-coated S-PRG resin blocks. Dent Mater J 33: 261-267.

32. Hahnel S, Wastl DS, Schneider-Feyrer S, Giessibl FJ, Brambilla E, et al (2014) Streptococcus mutans biofilm formation and release of fluoride from experimental resin-based composites depending on surface treatment and S-PRG filler particle fraction. J Adhes Dent 16: 313-321.

33. Ma S, Imazato S, Chen JH, Mayanagi G, Takahashi N, et al. (2012) Effects of a coating resin containing S-PRG filler to prevent demineralization of root surfaces. Dent Mater J 31: 909-915.

34. Tamura D, Saku S, Yamamoto K, Hotta M (2010) Adsorption of salivary protein to resin composite containing S-PRG filler. Jpn J Conserv Dent 53: 191-206.

35. Kuramochi E, Tomiyama K, Kumada H, Shiiya T, lizuka J, et al. (2014) Antibacterial effects of an S-PRG eluate on polymicorbial biofilms. Jpn J Conserv Dent 57: 414-420.

36. Suzuki N, Yoneda M2, Haruna K3, Masuo Y3, Nishihara T3, et al. (2014) Effects of S-PRG eluate on oral biofilm and oral malodor. Arch Oral Biol 59: 407-413.

37. Han L, Takenaka S, Okiji T (2007) Evaluation of selected properties of a prototyoe S-PRG filler containing root canal sealer. Jpn J Conserv Dent 50: 713-720.

38. Yoneda M, Suzuki N, Masuo Y, Fujimoto A, Iha K, et al. (2012) Effect of S-PRG Eluate on Biofilm Formation and Enzyme Activity of Oral Bacteria. Int J Dent 2012: 814913

39. Simón-Soro A, Mira A2 (2015) Solving the etiology of dental caries. Trends Microbiol 23: 76-82.

40. Tjäderhane L, Larjava H, Sorsa T, Uitto VJ, Larmas M, et al. (1998) The activation and function of host matrix metalloproteinases in dentin matrix breakdown in caries lesions. J Dent Res 77: 1622-1629.

41. Santos MC, de Souza AP, Gerlach RF, Trevilatto PC, Scarel-Caminaga RM, et al. (2004) Inhibition of human pulpal gelatinases (MMP-2 and MMP-9) by zinc oxide cements. J Oral Rehabil 31:660-664.

42. Nakamura N, Yamada A, Iwamoto T, Arakai M, Tanaka K, et al. (2009) Twoyear clinical evaluation of flowable composite resin containing pre-reacted glass-ionomer. Pediat Dent J 19: 89-97.

43. Suzuki N, Yoneda M, Hirofuji T (2013) Mixed red-complex bacterial infection in periodontitis. Int J Dent 2013: 587279.

44. Yoneda M, Hirofuji T, Anan H, Matsumoto A, Hamachi T, et al. (2001) Mixed infection of Porphyromonas gingivalis and Bacteroides forsythus in a murine abscess model: involvement of gingipains in a synergistic effect. J Periodontal Res 36: 237-243.

45. Weiss El, Shenitzki B, Leibusor R (1996) Microbial coaggregation in the ora cavity. Adv Exp Med Biol 408: 233-240.

46. Okuda T, Kokubu E, Kawana T, Saito A, Okuda K, et al. (2012) Synergy in biofilm formation between Fusobacterium nulceatum and Prevotella species. Anaerobe 18: 110-11.

47. Suzuki N, Yoneda M, Hirofuji T (2015) Evidence-based control of oral malodor In: Oral Health: In Tech: in press.

48. Morita M, Wang HL (2001) Association between oral malodor and adult periodontitis: a review. J Clin Periodontol 28: 813-819.

49. Verran J (2005) Malodour in denture wearers: an ill-defined problem. Oral Dis 11 Suppl 1: 24-28.

50. Shimazu K, Ogata K, Karibe K (2011) Evaluation of the ion-releasing and recharging abilities of a resin-based fissure sealant containing S-PRG filler Dent Mater J 30: 923-927.

51. Baker SJ, Akama T, Zhang YK, Sauro V, Pandit C, et al. (2006) Identification of a novel boron-containing antibacterial agent (AN0128) with anti-inflammatory activity, for the potential treatment of cutaneous diseases. Bioorg Medic Chem Lett 16:5963-5967.

52. Luan Q, Desta T, Chehab L, Sanders VJ, Plattner J, et al. (2008) Inhibition of experimental periodontitis by a topical boron-based antimicrobial. J Dent Res 87: $148-152$

53. Dembitsky VM, Al Quntar AA, Srebnik M (2011) Natural and synthetic small boron-containing molecules as potential inhibitors of bacterial and fungal quorum sensing. Chem Rev 111: 209-237.

54. Chen Z, Potempa J, Polanowski A, Wikstrom M, Travis J (1992) Purificaction and characterization of a 50-kda cystene proteinase (gingipain) from Porphyromonas gingivalis. J Biol Chem 267: 18896-19901

55. de Souza AP, Gerlach RF, Line SR (2000) Inhibition of human gingival gelatinase (MMP-2 and MMP-9) by metal salts. Dent Mater 16: 103-108. 
Citation: Yoneda M, Suzuki N, Hirofuji T (2015)Antibacterial Effect of Surface Pre-Reacted Glass lonomer Filler and Eluate-Mini Review. Pharm Anal Acta 6: 349. doi:10.4172/2153-2435.1000349

Page 5 of 5

56. Nikaido T, Weerasinghe DD, Waidyasekera K, Inoue G, Foxton RM, et al. (2009) Assessment of the nanostructure of acid-base resistant zone by the application of all-in-one adhesive systems: Super dentin formation. Biomed Mater Eng 19: 163-171.
57. Chen L, Shen $\mathrm{H}$, Suh $\mathrm{BI}$ (2012) Antibacterial dental restorative materials: a state-of-the-art review. Am J Dent 25: 337-346.

58. Imazato S (2009) Bio-active restorative materials with antibacterial effects: new dimension of innovation in restorative dentistry. Dent Mater J 28: 11-19. 